\title{
PERAN BADAN WAKAF INDONESIA (BWI) DALAM MENGEMBANGKAN PROSPEK WAKAF UANG DI INDONESIA
}

\author{
Muhammad Aziz \\ Sekolah Tinggi Agama Islam Al Hikmah Tuban \\ e-mail:mohaziv@yahoo.com
}

\begin{abstract}
Since established in 2007, The Indonesian Waqf Board (BWI) which is based upon the mandate of Law No. 41 of 2004 on waqf has had a significant role in the dynamics of waqf management in Indonesia. However, a significant role still has not been completed. The problems of waqf in Indonesia still exist, especially with regard to waqf money (cash waqf). The study is to answer question; how is the role of Indonesian Waqf Board and any effort which should be done, so that the potential of existing cash waqf in Indonesia can grow and develop. From this research, it can be concluded that the role of Indonesian Waqf Board in developing prospects in Indonesia is less maximal. Waqf money can not be mapped on the following things; First, professional nadhi coaching, particularly against individuals or legal entities who are given authority and responsibility as nadhi of money waqf. To improve the quality of human nadhi resources, it can be needed policies that are tentative, or even a steady, so that taste and look for nadhi usefulness. Second, involving strategic business partners engaged in financial services (especially sharia-based), such as banks, cooperatives, Bayt al-Ma\$wa al-Tamwi\$(BMT) and the like, in the process of promotion and dissemination of money waqf that is being developed by BWI. All that prospects and public confidence in the waqf money at BWI can flourish.
\end{abstract}

Keywords: cash waqf, Indonesian Waqf Board (BWI), nadhi〉

\section{Pendahuluan}

Sejak berdiri pada tahun 2007, Badan Wakaf Indonesia (BWI) yang lahir berdasarkan amanat UU Nomor 41 Tahun 2004 tentang Wakaf telah memiliki peran yang signifikan dalam dinamika pengelolaan wakaf yang ada di Indonesia.

Keberadaan BWI telah diatur dalam undang-undang wakaf secara jelas dan terperinci, dari pasal 47 sampai dengan pasal 61 Undang-Undang Nomor 41 Tahun 2004. Pada pasal 57 disebutkan bahwa untuk pertama kali, pengangkataan keanggotaan BWI diusulkan kepada Presiden oleh menteri. Sedangkan BWI dibentuk dan berkedudukan di Ibukota Negara Kesatuan Republik Indonesia dan dapat membentuk perwakilan di provinsi dan atau kabupaten/kota sesuai dengan kebutuhan. ${ }^{1}$

Adapun tugas Badan Wakaf Indonesia yaitu 1). Melakukan pembinaan terhadap nadhi〉 dalam mengelola dan mengembangkan harta benda wakaf; 2). Melakukan pengelolaan dan pengembangan harta benda wakaf berskala nasional dan internasional; 3). Memberikan persetujuan dan atau izin atas perubahan peruntukan dan status harta benda wakaf; 4). Memberhentikan dan mengganti nadhi», 5). Memberikan persetujuan atas penukaran harta benda wakaf; 6). Memberikan saran dan pertimbangan kepada pemerintah dalam penyusunan

\footnotetext{
${ }^{1}$ Lihat Peraturan BWI Nomor: 08/BWI/XII/2007 tentang Tata Keja Badan Wakaf Indonesia.
} 
kebijakan di bidang perwakafan.

Dilihat dari tugas kelembagaan, keberadaan Badan Wakaf Indonesia mempunyai posisi yang sangat strategis dalam pemberdayaan wakaf secara produktif. Pembentukan Badan Wakaf Indonesia (BWI) bertujuan untuk menyelenggarakan manajemen wakaf secara optimal, yang terkait dengan pengelolaan. Seperti harta wakaf yang bersifat nasional dan internasional yang keberadaannya masih terlantar maupun pembinaan terhadap nadhi yang kurang memadai. Badan Wakaf Indonesia (BWI) bersifat independen dan profesional yang bersinergi dengan peran pemerintah sebagai regulator (pengatur), fasilitator (memberi fasilitas), motivator (memberi semangat) dan public service (pelayanan umum). ${ }^{2}$

Khusus berkaitan dengan wakaf uang yang ada di Indonesia, setidaknya ada beberapa fakta baru tentang geliat luar biasa bagi umat Islam yang hendak berwakaf walaupun tidak memiliki aset tanah. Dalam konteks ini, tentunya banyak tantangan dan kendala yang dihadapi oleh BWI, khususnya berkaitan dengan pengembangan prospek dan potensi wakaf uang yang ada di Indonesia semakin hari semakin berkembang.

\section{Pengertian wakaf}

Secara bahasa kata wakaf (al-waqf) berarti al-hłbs yang secara bahasa Indonesia diartikan menahan. Hal ini sebagaimana perkataan seseorang waqafa-yaqifu-waqfan, artinya hłbasa-yahbisu-hłbsan. ${ }^{3}$ Kata al-waqf bila dijamakkan menjadi al-awqas dan al-wuquf, sedangkan bentuk kata kerjanya ( $f^{\prime}$ il) adalah waqafa. Menurut bahasa, waqafa berarti menahan atau mencegah, misalnya kata waqaftu 'an al-sayri, yang bermakna "saya menahan diri dari berjalan". Dalam peristilahan syara', wakaf adalah sejenis pemberian yang pelaksanaannya dilakukan dengan jalan menahan (pemilikan) asal (tahbis al-ashi), lalu menjadikan manfaatnya berlaku umum. ${ }^{4}$

Kata al-hłbs bermakna menahan harta dan memanfaatkan hasilnya di jalan Allah, atau ada juga yang bermaksud menghentikan seperti yang disebutkan di atas. Maknanya di sini, menghentikan manfaat keuntungannya dan diganti untuk amal kebaikan sesuai dengan tujuan wakaf. Menghentikan segala aktifitas yang pada mulanya diperbolehkan terhadap harta ('ain benda itu), seperti menjual, menghibahkan, mewariskan, mentransaksikan, maka setelah dijadikan harta wakaf hanya untuk keperluan agama semata bukan untuk keperluan si waæif atau individual lainnya. ${ }^{5}$

Sebagaimana dikutip oleh Abdul Halim, wakaf secara istilah menurut Muhammad Jawad Mughniyah adalah suatu bentuk pemberian yang menghendaki penahanan asal harta dan mendermakan hasilnya pada jalan yang bermanfaat. ${ }^{6}$

Menurut Sayyid Sabiq, wakaf berarti menahan harta dan memberikan manfaatnya di jalan Allah. ${ }^{7}$ Menurut al-Shan'ani, wakaf adalah menahan harta yang dapat diambil

\footnotetext{
2 Depatemen Agama Republik Indonesia, Proses Lahirnya Undang-Undang Nomor 41 Tahun 2004 Tentang Wakaf (Jakarta: Direktorat Pemberdayaan Wakaf Direktorat Jenderal Bimbingan Masyarakat Islam, 2006 ), 46.

${ }^{3}$ Sayyid Sabiq, Fiqh Sunnah, cet. Ke-I (Bandung: al-Ma'arif, 1987), 148.

${ }^{4}$ Muhammad Jawwad Mughniyah, Fiqh Lima Mazhab, cet. Ke-I (Jakarta: Basrie Press, 1997), 383.

${ }^{5}$ Abdul Halim, Hukum Perwakafan di Indonesia (Jakarta: Ciputat Press, 2005), 8.

${ }^{6}$ Ibid., 9.

${ }^{7}$ Sayyid Sabiq, Fiqh Sunnah, Juz III (Beirut: Dar al-Fikr, 1987), 426.
} 
manfaatnya tanpa menghabiskan atau merusakkan bendanya ('ain-nya) dan digunakan untuk kebaikan. ${ }^{8}$

Sedangkan pengertian wakaf dalam Pasal 1 Undang-Undang Nomor 41 Tahun 2004 tentang Wakaf, adalah perbuatan hukum wałif untuk memisahkan dan atau menyerahkan sebagian harta benda miliknya untuk dimanfaatkan selamanya atau untuk jangka waktu tertentu sesuai dengan kepentingannya guna keperluan ibadah dan atau kesejahteraan umum menurut Syariah. Jadi wakaf merupakan suatu perbuatan sunnah untuk tujuan kebaikan, seperti membantu pembangunan sektor keagamaan baik pembangunan di bidang material maupun spiritual. ${ }^{9}$

Dengan demikian wakaf merupakan tindakan hukum. Agar sah hukumnya, dan tercapai fungsi tujuannya, maka rukun dan syaratnya harus dipenuhi. Karena fungsi wakaf adalah mengekalkan manfaat benda wakaf sesuai dengan tujuannya, yaitu guna kepentingan ibadah atau keperluan umum lainnya sesuai dengan ajaran Islam. ${ }^{10}$

\section{Dasar Hukum Wakaf}

Dalil-dalil yang menjadi dasar disyariatkannya ibadah wakaf dapat dilihat dari beberapa ayat al-Quran meskipun tidak secara khusus menerangkan tentang wakaf dan beberapa hadis Nabi Muhammad SAW, antara lain:

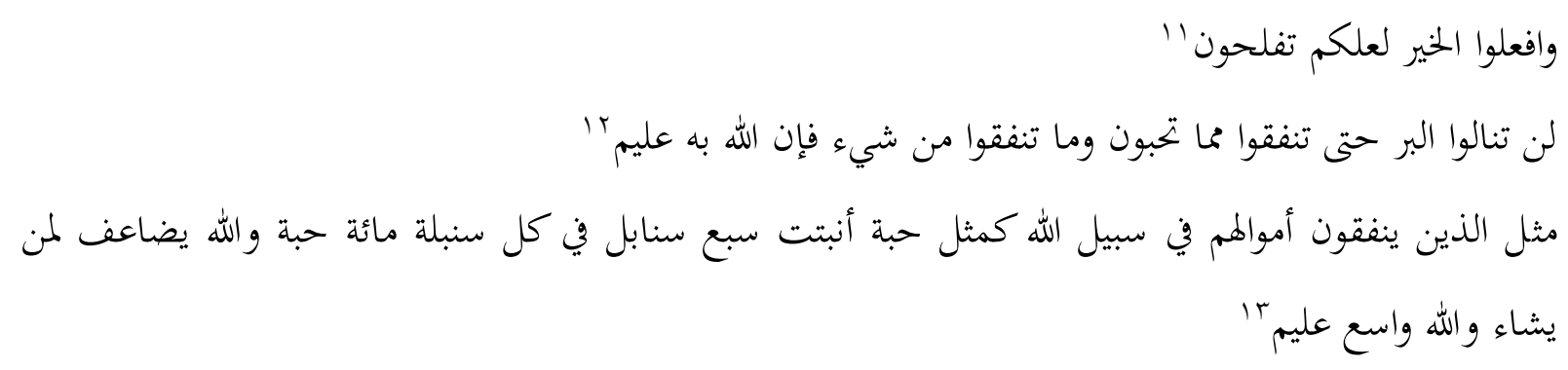

Selain hal tersebut di atas, terdapat banyak hadis yang menjelaskan ibadah wakaf. Salah satunya hadis yang diriwayatkan Ibn Umar ra:

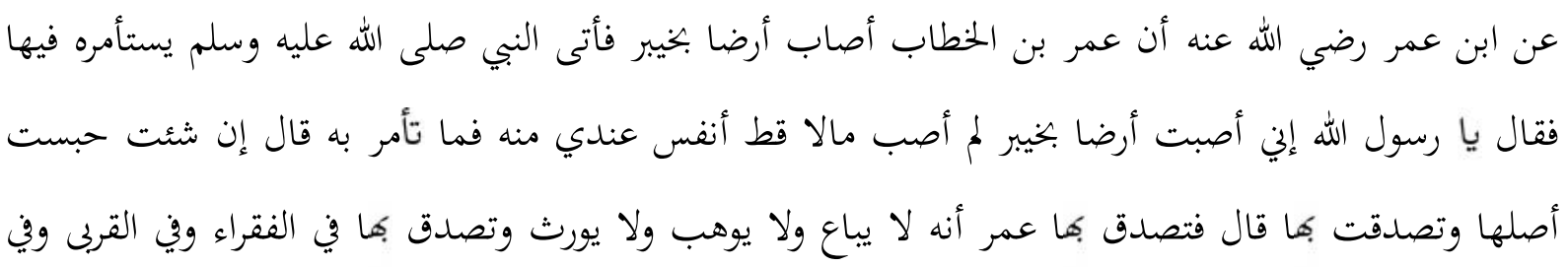

\footnotetext{
${ }^{8}$ Muhammad bin Isma'il al-Kahlani al-Shan'ani, Subul al-Salam, Juz III (Semarang: Toha Putra, t.th), 87.

${ }^{9} \mathrm{http}: / /$ candraboyseroza.blogspot.com/2009/02/wakaf-dalam-pandangan-ulama-fikih.

${ }^{10}$ Ahmad Rofiq, Fiqih Kontekstual dari Normatif ke Pemaknaan Sosial (Yogyakarta: Pustaka Pelajar, 2004), 320-321.

${ }^{11}$ al-Quran, 22: 77.

${ }^{12}$ Ibid., 3: 92.

${ }^{13}$ Ibid., 2: 261.
} 


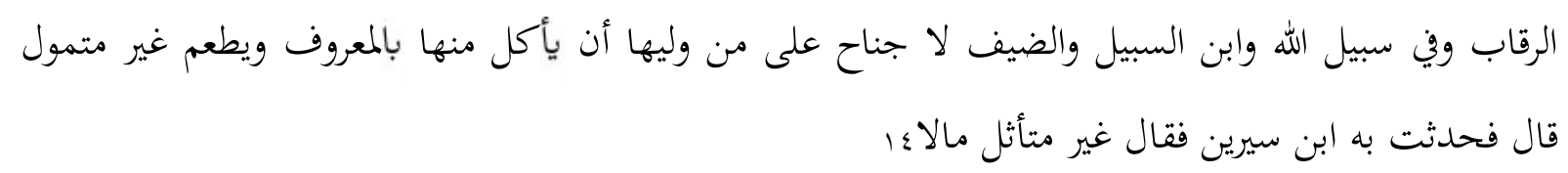

Hadits di atas menunjukkan bahwa wakaf adalah tindakan jæriyah, artinya meskipun orang yang menafkahkan telah meninggal dunia, pahalanya akan terus mengalir selama benda wakaf tersebut dimanfaatkan untuk kepentingan kebaikan. Dengan demikian sebagai bagian dari amal jariyah yang bersifat tabarru' atau tindakan sukarela yang tidak mengharapkan kontraprestasi (imbalan), Islam mengajarkan agar jika tangan kanan memberikannya, maka tangan kirinya tidak mengetahuinya. ${ }^{15}$

\section{Syarat dan Rukun Wakaf}

Meskipun para ulama berbeda pendapat dalam memberikan definisi mengenai wakaf, namun dalam ketentuan pelaksanaannya mereka sependapat bahwa di dalam syariat wakaf diperlukan adanya beberapa ketentuan baik yang berhubungan dengan rukun maupun syarat. Unsur-unsur (rukun) dan syarat yang harus dipenuhi dalam wakaf adalah:

1. Waæif atau orang yang mewakafkan

Pada hakekatnya amalan wakaf adalah tindakan tabarru' (mendermakan harta benda), oleh karena itu syarat seorang waæif adalah cakap untuk melakukan tindakan tabarru'. Artinya dewasa, sehat akal, dalam keadaan sadar, tidak dalam keadaan terpaksa atau dipaksa. ${ }^{16}$ Oleh karena itu, wakafnya orang-orang yang tidak memenuhi persyaratan di atas tidak sah.

2. Mauquङ atau benda yang diwakafkan

Benda yang diwakafkan harus memenuhi persyaratan, di antaranya 1). Benda wakaf dapat dimanfaatkan untuk jangka panjang, tidak sekali pakai; 2). Benda wakaf dapat berupa milik kelompok atau badan hukum; 3). Hak milik wakif yang jelas batas-batas kepemilikannya; 4). Benda wakaf itu dapat dimiliki dan dipindahkan kepemilikannya; 5). Benda wakaf dapat dialihkan hanya jika jelas-jelas untuk maslahat yang lebih besar; 6). Benda wakaf tidak dapat diperjualbelikan, dihibahkan atau diwariskan. ${ }^{17}$

Dalam Pasal 15 Undang-Undang Nomor 41 tahun 2004 tentang Wakaf, harta benda wakaf hanya dapat diwakafkan apabila dimiliki dan dikuasai wałif secara sah.

3. Mauqus'alaih atau penerima wakaf

Yang dimaksud dengan mauqus 'alaih adalah tujuan wakaf (peruntukan wakaf). Wakaf harus dimanfaatkan dalam batas-batas yang sesuai dan diperbolehkan syariat Islam. Karena pada dasarnya, wakaf merupakan amal yang mendekatkan diri manusia kepada Tuhan. Karena itu mauqus'alaih (yang diberi wakaf) haruslah pihak kebajikan. ${ }^{18}$

Oleh karena itu tujuan wakaf tidak bisa digunakan untuk kepentingan maksiat, atau membantu, mendukung, atau yang mungkin diperuntukkan untuk kepentingan maksiat.

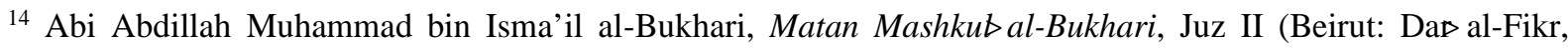
1994), 124.

${ }^{15}$ Ahmad Rofiq, Pembaharuan Hukum Islam di Indonesia (Yogyakarta: Gama Media, 2001), 124-125.

${ }^{16}$ Abi Yahya Zakariya al-Anshari, Fath\}al-Wahhab, Juz I (Semarang: Toha Putra, t.th.), 256.

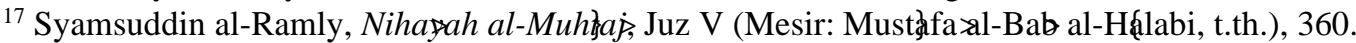

${ }^{18}$ Ahmad Rofiq, Pembaharuan Hukum Islam, 494-495.
} 
Menyerahkan wakaf kepada seseorang yang tidak jelas identitasnya adalah tidak sah. ${ }^{19}$

Dalam Undang-Undang Nomor 41 Tahun 2004 tentang wakaf, dijelaskan bahwa wakaf bertujuan memanfaatkan harta benda wakaf sesuai dengan fungsinya, yakni mewujudkan potensi dan manfaat ekonomis harta benda wakaf untuk kepentingan ibadah dan untuk memajukan kesejahteraan umum.

4. Sl s hah atau ikrar/pernyataan wakaf

Ikrar wakaf berdasarkan Pasal 1 ayat 3 Undang-Undang No.41 tahun 2004 tentang wakaf adalah: pernyataan kehendak waæif yang diucapkan secara lisan dan atau tulisan kepada nadhi $\gg$ untuk mewakafkan harta benda miliknya.

Pernyataan atau ikrar wakaf ini harus dinyatakan secara tegas baik lisan maupun tertulis, dengan redaksi "aku mewakafkan" atau "aku menahan" atau kalimat yang semakna lainnya. Ikrar ini penting, karena pernyataan ikrar membawa implikasi gugurnya hak kepemilikan wakif, dan harta wakaf menjadi milik Allah atau milik umum yang dimanfaatkan untuk kepentingan umum yang menjadi tujuan wakaf. ${ }^{20}$

5. Nadhi $\gg$ atau pengelola wakaf

Pada umumnya di dalam kitab-kitab fikih tidak mencantumkan nadhi $\gg$ wakaf sebagai salah satu rukun wakaf. Ini dapat dimengerti karena wakaf adalah perbuatan tabarru'. Namun demikian memperhatikan tujuan wakaf yang ingin melestarikan manfaat dari benda wakaf, maka nadhi $\gg$ sangat diperlukan. ${ }^{21}$

Pada dasarnya siapapun dapat saja menjadi nadhi $\gg$ asalkan ia tidak terhalang melakukan tindakan hukum. Akan tetapi karena fungsi nadhi $\gg$ sangat penting dalam perwakafan maka diberlakukan syarat-syarat nazhir. Para imam mazhab sepakat bahwa nadhi $\gg$ harus memenuhi syarat adil dan mampu. Para ulama berbeda pendapat mengenai ukuran adil. Jumhur ulama berpendapat bahwa yang dimaksud adil adalah mengerjakan yang diperintahkan dan menjauhi yang dilarang syariat. ${ }^{22}$ Sedangkan "mampu" menurut Ahmad Rofiq adalah memiliki kreativitas (zara'y). Hal ini didasarkan pada perbuatan Umar menunjuk Hafsah menjadi nadhi $\gg$ karena ia dianggap mempunyai kreativitas. $^{23}$

Adapun persyaratan untuk menjadi seorang nadhi $\gg$ berdasarkan Pasal 10 UndangUndang Nomor 41 tahun 2004 haruslah memenuhi syarat sebagai berikut: ${ }^{24} 1$ ). warga negara Indonesia; 2). beragama Islam; 3). dewasa; 4). amanah; 5). mampu secara jasmani dan rohani; 6). tidak terhalang melakukan perbuatan hukum.

6. Jangka waktu wakaf

Dalam buku-buku maupun peraturan perundangan wakaf sebelum munculnya Undang-Undang Nomor 41 tahun 2004 tentang wakaf tidak dicantumkan rukun wakaf mengenai adanya jangka waktu pelaksanaan wakaf, hal ini merupakan terobosan baru yang dilakukan pemerintah, mengingat manfaat wakaf pada dasarnya adalah untuk kesejahteraan umat.

Jangka waktu wakaf sebagaimana tercantum dalam Pasal 6 Undang-Undang Wakaf

\footnotetext{
${ }^{19}$ Ibid., 496 .

${ }^{20}$ Ibid., 497.

${ }^{21}$ Ibid., 498.

${ }^{22}$ Said Agil Husain al-Munawwar, Hukum Islam dan Pluralitas Sosial (Jakarta: Penamadani, 2004), 161.

23 Ahmad Rofiq, Pembaharuan Hukum Islam, 499.

${ }^{24}$ Undang-Undang RI Nomor 41 tahun 2004 tentang Wakaf.
} 
Nomor 41 tahun 2004, yakni waæif diperbolehkan membatasi waktu wakafnya, artinya wąif hanya mewakafkan manfaat dari benda yang diwakafkannya, dan setelah jangka waktu tersebut habis waæif diperbolehkan meminta kembali benda yang diwakafkannya.

\section{Macam-macam wakaf}

Wakaf terbagi menjadi beberapa macam berdasarkan tujuan, batasan waktunya, dan penggunaan barangnya. Macam-macam wakaf berdasarkan tujuannya ada tiga, yaitu 1). wakaf sosial untuk kebaikan masyarakat (waqf al-khairi); yaitu apabila tujuan wakafnya untuk kepentingan umum. 2). wakaf keluarga (waqf al-dhurri); yaitu apabila tujuan wakaf untuk memberi manfaat kepada wakif, keluarganya, keturunannya, dan orang-orang tertentu tanpa melihat apakah kaya atau miskin, sakit atau sehat, dan tua atau muda. ${ }^{25} 3$ ). wakaf gabungan (waqf al-mushtarak); yaitu apabila tujuan wakafnya untuk umum dan keluarga bersamaan. ${ }^{26}$

Sedangkan berdasarkan batasan waktunya, wakaf terbagi menjadi dua macam, yaitu 1). wakaf abadi (waqf al-muabbad); yaitu apabila wakafnya berbentuk barang yang bersifat abadi, seperti tanah dan bangunan dengan tanahnya, atau barang bergerak yang ditentukan oleh waæif sebagai wakaf abadi dan produktif, dimana sebagian hasilnya untuk disalurkan sesuai tujuan wakaf, sedangkan sisanya untuk biaya perawatan wakaf dan mengganti kerusakannya. 2). wakaf sementara (waqf al-muaqqat); yaitu apabila barang yang diwakafkan berupa barang yang mudah rusak ketika dipergunakan tanpa memberi syarat untuk mengganti bagian yang rusak. Wakaf sementara juga bisa dikarenakan oleh keinginan wałif yang memberi batasan waktu ketika mewakafkan barangnya. ${ }^{27}$

Selanjutnya pembagian wakaf berdasarkan penggunaannya dibagi menjadi dua macam, yaitu 1). wakaf langsung, yaitu wakaf yang pokok barangnya digunakan untuk mencapai tujuannya, seperti masjid untuk salat, sekolah untuk kegiatan belajar mengajar, rumah sakit untuk mengobati orang sakit dan lain sebagainya; 2). wakaf produktif, yaitu wakaf yang pokok barangnya digunakan untuk kegiatan produksi dan hasilnya diberikan sesuai dengan tujuan wakaf.

Tiga pembagian wakaf di atas sudah mencakup jenis keseluruhan wakaf, baik berdasarkan tujuan, batasan waktunya, maupun penggunaannya. Selanjutnya kita akan mempelajari secara mendalam tentang perbedaan mendasar antara amalan filantropi dalam Islam yang ada. ${ }^{28}$

\section{Wakaf Uang}

Orientasi wakaf konsumtif cenderung membuat para pengelola menghindari usahausaha produktif. Dampaknya adalah wakaf langsung digunakan dan tidak diinvestasikan secara produktif. Karena itu diperlukan reformasi wakaf ke arah yang lebih produktif. Salah satu bentuk wakaf produktif yang paling potensial untuk berkembang adalah wakaf uang.

\footnotetext{
${ }^{25}$ Suparman Usman, Hukum Perwakafan di Indonesia (Serang: Darul Ulum Press, 1999), 34.

${ }^{26}$ Ibrahim al-Bayumi Ghanim, al-Auqaßwa al-Siyasah fi ¥isła (Mesir: Da»al-Ashshirk, t.th), 55.

27 Ibid., 56.

${ }^{28}$ Ahmad Djunaidi, Menuju Era Wakaf Produktif(Jakarta: Map Mumtaz Publizhing, 2008), 65.
} 
Dalam sejarah Islam, orang yang pertama kali mengenalkan wakaf uang adalah Imam Zufar (abad ke-8M), salah seorang ulama Mazhhab Hanafi. Imam Zufar menggariskan bahwa dana wakaf uang harus diinvestasikan melalui mudłrabah dan keuntungannya dibelanjakan untuk charity. Imam Bukhari dan Ibn Syihab al-Zuhri juga menyatakan hal serupa. ${ }^{29}$ Imam Bukhari menyebutkan bahwa Imam al-Zuhri membolehkan mewakafkan dinar dan dirham. Caranya ialah menjadikan dinar dan dirham tersebut sebagai modal usaha (dagang), kemudian menyalurkan keuntungannya sebagai wakaf. Al-Zuhri salah seorang ulama terkemuka dan peletak dasar tadwiłal-hadiłh itu memfatwakan bahwa masyarakat dianjurkan mewakafkan dinar dan dirham untuk pembangunan sarana dakwah, sosial, dan pendidikan umat Islam saat itu. Kebolehan wakaf uang juga dikemukakan oleh Mazhab Hanafi. Bahkan sebagian ulama Mazhab Syafi'i juga membolehkan wakaf uang.

Sejarah menunjukkan bahwa wakaf uang telah populer pada zaman Bani Mamluk dan Turki Usmani. Di awal perkembangan Islam pun, wakaf uang telah dibenarkan oleh para ulama. Namun demikian, wakaf uang baru menemukan bentuknya yang matang pada masa Turki Usmani (abad ke-16M). ${ }^{30}$ Pembangunan kota Istambul (1453M) tak lepas dari wakaf uang untuk mendirikan pusat-pusat perdagangan. Bukti sejarah berupa dokumen wakaf uang pertama kali ditemukan di Istanbul pada tahun 1464. Seratus tahun kemudian, wakaf uang menjadi kebiasaan masyarakat Istanbul. ${ }^{31}$

Di Timur Tengah, wakaf uang sudah lama dipraktikkan. Di Mesir, misalnya, Universitas al-Azhar menjalankan aktivitasnya dengan menggunakan dana wakaf. Universitas tersebut mengelola gudang dan perusahaan di Terusan Suez. Universitas Al-Azhar selaku nadhi $\gg$ hanya mengambil hasilnya untuk keperluan pendidikan. Pemerintah Mesir pernah meminjam dana wakaf Al-Azhar untuk operasional pemerintahan. Di Qatar dan Kuwait, dana wakaf uang dipergunakan untuk membangun perkantoran, menyewakannya, dan hasilnya digunakan untuk kegiatan umat Islam. Tak ketinggalan, Sudan juga menjalankan wakaf uang. Sejak 1987, Sudan membenahi manejemen wakafnya dengan membentuk Badan Wakaf yang memiliki kewenangan yang lebih luas termasuk dalam aspek pengelolaan wakaf uang. Sejarah telah menunjukkan bahwa berkat wakaf uang, Universitas al-Azhar, Universitas Zaituniyyah di Tunis, serta Madaris Imam Lisesi di Turki mampu bertahan hingga kini meski mereka tidak berorientasi pada keuntungan.

M. A. Mannan mengangkat kembali konsep wakaf uang melalui pembentukan Social Investment Bank Limited (SIBL) di Bangladesh yang dikemas dalam mekanisme instrumen cash waqf certificate. Ia telah memberikan solusi alternatif dalam mengatasi krisis kesejahteraan umat Islam. Dibandingkan dengan wakaf harta tak bergerak lain, wakaf uang memiliki peluang yang lebih besar untuk dilakukan modernisasi. ${ }^{32}$

Wakaf uang adalah wakaf berupa uang dalam bentuk rupiah yang kemudian dikelola oleh nadhi secara produktif, hasilnya dimanfaatkan untuk mauqus alaih. Dengan demikian, dalam wakaf uang, uang yang diwakafkan tidak boleh diberikan langsung kepada mauqu^

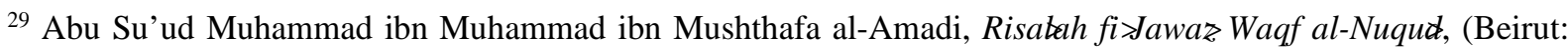

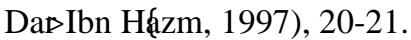

${ }^{30}$ Murat Cizakca, "Outlines Incorporated Waqfs", Waqf for the Development of the Umma, Johor Bahru 11 Agustus 2008, 7-12.

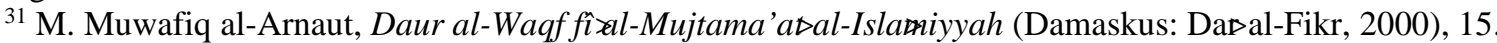

${ }^{32}$ Murat Cizakca, "Outlines Incorporated Waqfs", 3.
} 
'alaih, tetapi harus diinvestasikan lebih dulu oleh nadhi», kemudian hasil investasinya diberikan kepada mauqu^ alaih. Di Indonesia, Baitul Mal Muamalat, Tabung Wakaf Indonesia, dan PKPU telah berupaya menjadi nadhi $\gg$ wakaf uang, walaupun masih terdapat keragaman konsep dan aplikasinya.

Pada mulanya, hukum mewakafkan uang menjadi perdebatan di kalangan ulama fikih. Perdebatan bermula dari penafsiran terhadap sabda Rasulullah kepada Umar ibn Khattab:

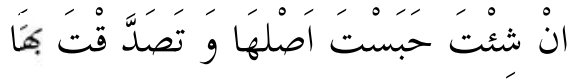

"Kalau kamu berkenan, tahan pokoknya dan sedekahkan hasilnya“

Dari kata "tahan pokoknya" ini kemudian dipahami harta wakaf harus tetap materialnya. Persoalan berkembang, apakah uang secara material bisa tetap? Bukankah ada fenomena inflasi? Bukankah ia bisa habis dikonsumsi?

Alasan ulama yang tidak membolehkan wakaf uang antara lain pertama, uang bisa habis zatnya sekali pakai. Uang hanya bisa dimanfaatkan dengan membelanjakan sehingga bendanya lenyap. Sedangkan inti ajaran wakaf adalah pada kesinambungan hasil dari modal dasar yang tetap lagi kekal, tidak habis sekali pakai. Oleh karena itu ada persyaratan agar benda yang akan diwakafkan itu adalah benda yang tahan lama, tidak habis sekali pakai. Kedua, uang seperti dinar dan dirham diciptakan sebagai alat tukar yang memudahkan orang melakukan transaksi jual beli, bukan untuk ditarik manfaatnya dengan mempersewakan zatnya.

Namun, mereka yang melarang wakaf uang mendapat bantahan dari mereka yang membolehkannya. Imam Malik, Ahmad ibn Hanbal, Imam Bukhari, dan Ibn Syihab al-Zuhri adalah eksponen yang membolehkan wakaf uang. ${ }^{33}$ Wahbah al-Zuhaili, dalam al-Fiqh alIsla riy wa Adillatuh menyebutkan bahwa Mazhab Hanafi membolehkan wakaf uang, karena substansi uang yang menjadi modal usaha itu dapat bertahan lama dan banyak manfaatnya untuk kemaslahatan umat. Caranya, menurut mazhab Hanafi ialah dengan menjadikannya sebagai modal usaha secara mudłł menerima wakaf. Jadi, mereka yang membolehkan wakaf uang lebih melihat bahwa "pokok" dalam hadits Rasulullah itu tidak dipahami sebagai material, tetapi substansi (nilai). Bagaimanapun juga, uang juga mempunyai substansi yang relatif tetap. Buktinya, orang bisa melakukan pinjam-meminjam uang. Itu artinya, uang memiliki substansi.

Mereka yang membolehkan wakaf uang, juga mempertimbangkan manfaat wakaf uang. Di antara manfaat yang bisa diambil adalah: ${ }^{34}$

1. Memiliki tingkat likuiditas tinggi. Ini berbeda dengan wakaf benda tak bergerak. Likuiditas adalah tingkat kemudahan atau kesulitan menukarkan dana (funds) dengan kas dalam waktu singkat dengan biaya yang wajar.

\footnotetext{
${ }^{33}$ al-Bakistani, "Tarjamah al-Musłnnif”, dalam al-Afandi al-Hanafi, Risałah fi $\gg$ awa Waqf al-Nuquæ, 13.

${ }^{34}$ M.A. Mannan, "Beyond the Malaysian Twin Towers: Mobilization Efforts of Cash-Waqf Fund at Local, National and International Levels for Development of Social Infrastructure of the Islamic Ummah and Establishment of World Social Bank", International Seminar on Awqaf 2008 - Awqaf: The Social and Economic Empowerment of the Ummah, Johor Bahru 11-12 Agustus 2008, Persada Johor International Convention Center, 10.
} 
2. Seseorang yang memiliki dana kecil sudah bisa berwakaf tanpa harus menunggu menjadi kaya terlebih dahulu. Kesempatan berwakaf tidak hanya dimiliki oleh orang kaya. SIBL misalnya, mengeluarkan sertifikat wakafnya hingga nilai US\$ 21 atau sekitar 210 ribu rupiah. BMM menurunkan hingga 100 ribu rupiah. Dalam konteks Indonesia, sertifikat wakaf uang dapat dibuat dalam berbagai macam pecahan yang disesuaikan dengan segmen muslim yang memiliki kesadaran beramal tinggi. Misalkan Rp. 10.000,-, Rp. 25.000,-50.000,-, Rp. 100.000,- Rp. 500.000,- Rp. 1.000.000,- Rp. 2.000.000.

3. Sarana efektif untuk pemerataan kekayaan dari si kaya ke si miskin. Wakaf uang akan memberikan kontribusi yang besar bagi upaya mengatasi problem kemiskinan dan kebodohan yang mendera bangsa ini.

4. Melalui wakaf uang, aset-aset wakaf berupa tanah kosong bisa dimanfaatkan dengan pembangunan sarana yang lebih produktif untuk kepentingan ummat. Wakaf uang dapat menjadi sumber pendanaan pengelolaan wakaf tak bergerak termasuk dalam pengembangan wakaf properti seperti yang terjadi di Bangladesh.

5. Membuka peluang umat Islam untuk lebih mandiri dalam mengembangkan dunia pendidikan tanpa harus terlalu bergantung pada anggaran negara yang terbatas.

6. Menjadi sarana pemberdayaan tabungan sosial.

7. Dapat ditransformasi oleh bank dari tabungan sosial menjadi modal sosial.

8. Keuntungan pengelolaannya untuk masyarakat miskin.

9. Menciptakan kesadaran di kalangan orang-orang kaya mengenai tanggung jawab sosial mereka terhadap masyarakat miskin.

10. Menciptakan keamanan sosial dan kedamaian sosial.

\section{Profil Badan Wakaf Indonesia}

\section{Sejarah Pendirian Badan Wakaf Indonesia}

Badan Wakaf Indonesia (BWI) adalah lembaga negara independen yang dibentuk berdasarkan Undang-Undang Nomor 41 Tahun 2004 tentang Wakaf. Badan ini dibentuk dalam rangka mengembangkan dan memajukan perwakafan di Indonesia.

BWI dibentuk bukan untuk mengambil alih aset-aset wakaf yang selama ini dikelola oleh nadhi (pengelola aset wakaf) yang sudah ada. BWI hadir untuk membina nadhi $\gg$ agar aset wakaf dikelola lebih baik dan lebih produktif sehingga bisa memberikan manfaat lebih besar kepada masyarakat, baik dalam bentuk pelayanan sosial, pemberdayaan ekonomi, maupun pembangunan infrastruktur publik.

BWI berkedudukan di ibukota Negara dan dapat membentuk perwakilan di provinsi, kabupaten, dan atau kota sesuai dengan kebutuhan. Anggota BWI diangkat dan diberhentikan oleh Presiden. Masa jabatannya selama 3 tahun dan dapat diangkat kembali untuk satu kali masa jabatan. Jumlah anggota BWI 20 sampai dengan 30 orang yang berasal dari unsur masyarakat. Anggota BWI periode pertama diusulkan oleh Menteri Agama kepada Presiden. Periode berikutnya diusulkan oleh Panitia Seleksi yang dibentuk BWI. Adapun anggota perwakilan BWI diangkat dan diberhentikan oleh BWI.

Struktur kepengurusan BWI terdiri atas Dewan Pertimbangan dan Badan Pelaksana. Masing-masing dipimpin oleh seorang ketua yang dipilih dari dan oleh para anggota. Badan 
Pelaksana merupakan unsur pelaksana tugas, sedangkan Dewan Pertimbangan adalah unsur pengawas. $^{35}$

\section{Visi, misi dan strategi Badan Wakaf Indonesia}

Visi dan Misi Badan Wakaf Indonesia adalah dalam rangka mewujudkan lembaga independen yang dipercaya masyarakat, mempunyai kemampuan dan integritas untuk mengembangkan perwakafan nasional dan internasional. Sedangkan misi menjadikan Badan Wakaf Indonesia sebagai lembaga profesional yang mampu mewujudkan potensi dan manfaat ekonomi harta benda wakaf untuk kepentingan ibadah dan pemberdayaan masyarakat. ${ }^{36}$

Sedangkan strategi yang digunakan BWI dalam mengembangan pengelolaan wakaf antara lain 1). meningkatkan kompetensi dan jaringan BWI, baik nasional maupun internasional; 2). membuat peraturan dan kebijakan di bidang perwakafan; 3). meningkatkan kemauan dan kesadaran masyarakat untuk berwakaf; 4). meningkatkan profesionalitas dan keamanahan nadhi $\gg$ dalam pengelolaan dan pengemabangan harta wakaf; 5). mengkoordinasi dan membina seluruh nadhi wakaf; 6). menertibkan administrasi harta benda wakaf; 7). menghimpun, mengelola dan mengembangkan harta benda wakaf yang berskala nasional dan internasonal.

\section{Struktur Lembaga Badan Wakaf Indonesia}

Susunan Pengurus Badan Wakaf Indonesia Masa Jabatan Tahun 2014-2017 37

Dewan Pertimbangan

$\begin{array}{ll}\text { Ketua } & \text { : Prof. Dr. H. Nur Syam, M.Si. } \\ \text { Wakil Ketua } & \text { : Prof. Dr. Abdul Djamil, M.A } \\ \text { Anggota } & \text { : Prof. Dr. Syibli Syarjaya } \\ & \text { : Prof. Dr. Veithzal R } \\ & \text { : Drs. H. Arifin Nurdin, S.H., M.Kn. }\end{array}$

\section{$\underline{\text { Badan Pelaksana }}$}

$\begin{array}{ll}\text { Ketua } & \text { : Dr. H. Maftuh Basyuni, S.H. } \\ \text { Wakil Ketua } & \text { : Drs. H. Slamet Riyanto, M.Si. } \\ \text { Sekretaris } & \text { : Ir. M. Nadratuzzaman Hosen, M.Ec., Ph.D. } \\ \text { Wakil Sekretaris } & \text { : Dr. H. Nursamad Kamba } \\ & \text { : Hj. Dra. Hamka, M.Ag. } \\ \text { Bendahara } & : \text { H. M. Mardini } \\ \text { Wakil Bendahara } & \text { : H. Abdul Qodir, S.H., M.A. }\end{array}$

Divisi-Divisi

Pembinaan Nadhi» : Drs. Entjeng Shobirin Nadj

: Dr. Asep Saepudin Jahar

\footnotetext{
${ }^{35}$ http://www.bwi.or.id, diakses pada 2 April 2015.

36 Ibid.

${ }^{37}$ Ibid.
} 
: Dr. KH. Mohamad Hidayat

Pengelolaan dan Pemberdayaan Wakaf

: Ir. Jurist Efrida Robbiyantono

: Ir. Iwan Agustiawan Fuad, M.Si.

: Dr. Muhammad Maksum, M.A.

Hubungan Masyarakat

: Ir. H. M. Khoirul Huda

: Dr. Jeje Jaenudin, M.Ag.

Kelembagaan dan Bantuan Hukum

: H. M. Sholeh Amin, S.H., M.Hum.

: Drs. Zafrullah Salim, M.H.

: Dr. Yusuf Susilo, S.H., M.Hum.

: Siti Soraya Devi Zaeni, S.H., M.Kn.

Penelitian dan Pengembangan

: Prof. Dr. Muhammad Zilal Hamzah

: Dr. Amelia Fauzia

Kerjasama Luar Negeri

: Dr. Muhamad Luthfi

: H. Arif Zamhari, Ph.D.

\section{Tugas dan Wewenang Badan Wakaf Indonesia}

Berdasarkan Pasal 49 Ayat 1 Undang-Undang Nomor 41 Tahun 2004 tentang Wakaf, BWI mempunyai tugas dan wewenang, yaitu pertama, melakukan pembinaan terhadap nadhi dalam mengelola dan mengembangkan harta benda wakaf. Kedua, melakukan pengelolaan dan pengembangan harta benda wakaf berskala nasional dan internasional. Ketiga, memberikan persetujuan dan atau izin atas perubahan peruntukan dan status harta benda wakaf. Keempat, memberhentikan dan mengganti nadhi». Kelima, memberikan persetujuan atas penukaran harta benda wakaf. Keenam, memberikan saran dan pertimbangan kepada Pemerintah dalam penyusunan kebijakan di bidang perwakafan. ${ }^{38}$

Kemudian, melalui Peraturan BWI Nomor 1 Tahun 2007 tentang Organisasi dan Tata Kerja Badan Wakaf Indonesia, BWI menjabarkan tugas dan wewenangnya:

1. Melakukan pembinaan terhadap nadhi $\triangleright$ dalam mengelola dan mengembangkan harta benda wakaf.

2. Membuat pedoman pengelolaan dan pengembangan harta benda wakaf.

3. Melakukan pengelolaan dan pengembangan harta benda wakaf berskala nasional dan internasional serta harta benda wakaf terlantar.

4. Memberikan pertimbangan, persetujuan, dan atau izin atas perubahan peruntukan dan status harta benda wakaf.

5. Memberikan pertimbangan dan atau persetujuan atas penukaran harta benda wakaf.

6. Memberikan saran dan pertimbangan kepada pemerintah dalam penyusunan kebijakan di bidang perwakafan.

\footnotetext{
${ }^{38}$ Ibid.
} 
7. Menerima, melakukan penilaian, menerbitkan tanda bukti pendaftaran nadhi», dan mengangkat kembali nadhi >yang telah habis masa baktinya.

8. Memberhentikan dan mengganti nadhi bila dipandang perlu.

9. Memberikan saran dan pertimbangan kepada Menteri Agama dalam menunjuk Lembaga Keuangan Syariah Penerima Wakaf Uang (LKS-PWU).

10. Menerima pendaftaran Akta Ikrar Wakaf (AIW) benda bergerak selain uang dari Pejabat Pembuat Akta Ikrar Wakaf (PPAIW).

Dalam melaksanakan tugas dan wewenangnya BWI bekerja sama dengan Kementerian Agama (c.q. Direktorat Pemberdayaan Wakaf), Majelis Ulama Indonesia, Badan Pertanahan Nasional, Bank Indonesia, Badan Perencanaan Pembangunan Nasional, Islamic Development Bank, dan berbagai lembaga lain. Tidak tertutup kemungkinan BWI juga bekerja sama dengan pengusaha atau investor dalam rangka mengembangkan aset wakaf agar menjadi lebih produktif.

\section{Peran BWI dalam Mengembangkan Potensi Wakaf Uang di Indonesia}

\section{Potensi Wakaf Uang di Indonesia}

Dalam konteks Indonesia, bahwa salah satu yang membawa kemajuan fundamental dan luar biasa perwakafan di Indonesia adalah lahirnya Undang-Undang Nomor 41 tahun 2004 tentang Wakaf, di mana dengan regulasi ini bahwa selain merubah paradigma wakaf ${ }^{39}$ di Indonesia dan juga merubah kebijakan wakaf di Indonesia, yaitu diakomodirnya wakaf uang yang merupakan bagian dari wakaf di Indonesia. Bahkan lebih luas dari itu bahwa dengan Undang-Undang Nomor 41 tentang Wakaf, kini wakaf di Indonesia tidak lagi hanya dipahami wakaf benda tidak bergerak yang berupa tanah seperti yang dipahami selama ini, tetapi wakaf dibagi kepada dua bagian, yaitu 1). wakaf benda tidak bergerak yang berupa tanah yang meliputi hak atas tanah sesuai dengan ketentuan peraturan perundang-undangan yang berlaku baik yang sudah maupun yang belum terdaftar, bangunan atau bagian bangunan yang berdiri di atas tanah, tanaman dan benda lain yang berkaitan dengan tanah, hak milik atas satuan rumah susun sesuai dengan ketentuan peraturan perundang-undangan yang berlaku, benda tidak bergerak lain sesuai dengan ketentuan syariah dan peraturan perundang-undangan; dan 2). wakaf benda bergerak, seperti uang, logam mulia, surat berharga, hak atas kekayaan intelektual (HAKI), kendaraan, hak sewa, dan benda bergerak lain sesuai dengan ketentuan syariah dan peraturan perundang-undangan yang berlaku. ${ }^{40}$

Pembagian wakaf di Indonesia tersebut yang merupakan bagian dari kemajuan wakaf di Indonesia, adapun pembagian wakaf tersebut adalah pertama, wakaf benda tidak bergerak

\footnotetext{
${ }^{39}$ Undang-Undang Nomor 41 Tahun 2004 tentang Wakaf membawa perubahan fundamental dan kemajuan luar biasa dalam perwakafan di Indonesia karena sebelum tahun 2004 wakaf di Indonesia umumnya dipahami dan diimplementasikan untuk kepentingan ibadah dalam bentuk: Masjid, mushalla, madrasah, rumah yatim piatu, kuburan dan lain sebagainya berakibat selain Indonesia ketertinggalan dalam pembangunan wakaf produktif dapat dilihat dari kebijakan wakaf berdasarkan PP Nomor 28 Tahun 1977 tentang Perwakafan Tanah Milik dan Nadhi sebagai penerima harta benda wakaf tidak memiliki kemampuan mengelola dan mengembangkan. Sebaliknya setelah merespon dan mengakomodir paradigma wakaf para ulama salaf dan khalas membawa perubahan paradigm dan kebijakan wakaf 100 derajat di Indonesia.

${ }^{40}$ Departemen Agama RI Ditjen Bimas Islam, Undang-Undang Nomor 41 Tahun 2004 tentang Wakaf dan Peraturan Pemerintah Nomor 42 Tahun 2006 tentang Pelaksanaan Undang-Undang Nomor 41 Tahun 2004 tentang Wakaf (Jakarta: Departemen Agama RI Ditjen Bimas Islam, 2007), 10-12.
} 
berupa tanah, yang terdiri dari 1). hak atas tanah sesuai dengan ketentuan yang berlaku; 2). bangunan atau bagian bangunan yang berdiri di atas tanah; 3). tanaman dan benda lain yang berkaitan dengan tanah; 4). hak milik atas satuan rumah susun sesuai dengan ketentuan perundang-undangan yang berlaku; 5). benda tidak bergerak lain yang sesuai dengan syariah dan ketentuan peraturan perundang-undangan yang berlaku. Kedua, wakaf benda bergerak, yang terdiri dari 1). wakaf uang; 2). logam mulia; 3). surat berharga; 4). hak atas kekayaan intelektual (HAKI); 5). kendaraan; 6). hak sewa; 7). benda bergerak lainnya yang sesuai dengan syariah dan ketentuan peraturan perundang-undangan yang berlaku.

Paradigma dan kebijakan wakaf di Indonesia merupakan paradigma dan kebijakan yang revolusioner, kontekstual, modern, produktif dan konstruktif karena telah merespon dan mengakomodir peradaban umat manusia. Dengan paradigma dan kebijakan wakaf tersebut, Indonesia telah sejajar dengan negara lain yang telah lama mengembangkan wakaf produktif, seperti Mesir, Kuwait, Uni Emirat Arab, Qatar, dan lain sebagainya. Paradigma dan kebijakan wakaf di Indonesia itu pula kini telah terbuka akses yang seluas-luasnya baik umat Islam maupun negara ${ }^{41}$ bukan hanya membangun tetapi juga mendukung dan mendorong sepenuhnya setiap langkah-langkah dan usaha-usaha positif-konstruktif pemberdayaannya sehingga wakaf ini dapat dikelola dan dikembangkan guna memberikan manfaat bagi kesejahteraan dan kemajuan umat, bangsa dan negara Indonesia yang luar biasa potensinya.

Pada tahun 2002, Majelis Ulama Indonesia (MUI) telah menetapkan fatwa yang membolehkan wakaf uang. Ketua MUI, KH. Ma'ruf Amin, menyatakan wakaf uang adalah sesuatu yang memiliki nilai yang diwakafkan untuk kepentingan masyarakat. Dia mengatakan:

"Dulu wakaf uang diperdebatkan tapi kini tidak lagi. Yang penting 'ain-nya tidak berkurang dan nilainya tetap, bisa dipertahankan. Tidak ada batas minimal atau maksimal besaran wakaf uang. Yang penting, uang itu milik sendiri dan didapat dengan cara yang halal".

Wakaf uang di Indonesia saat ini dari segi infrastrukturnya telah lengkap dan tinggal pelaksnaannya saja, karena semuanya telah diatur secara terperinci dalam perundangundangan tentang wakaf. ${ }^{42}$ Direktur Pemberdayaan Wakaf Direktorat Jenderal Bimbingan Masyarakat Islam, Sumuran Harahap menyatakan bahwa seandainya nadhi di Indonesia mampu mengumpulkan, mengelola dan mengembangkan wakaf, mereka bekerja secara professional dan amanah, maka wakaf di Indonesia bisa menjadi lokomotif perekonomian umat, bangsa dan Negara Indonesia.

Ketua Umum Ikatan Ahli Ekonomi Islam Indonesia (IAEI) yang juga Wakil Ketua Badan Wakaf Indonesia (BWI), Mustafa Edwin Nasution mengemukakan bahwa sesungguhnya keberadaan Negara Indonesia yang merupakan berpenduduk muslim terbesar di

\footnotetext{
${ }^{41}$ Negara adalah bagian dunia yang ada di bawah kekuasaan suatu pemerintahan yang berdaulat, merupakan organisasi yang di adakan oleh suatu atau beberapa bangsa yang berdiam dalam suatu daerah tertentu, untuk memelihara hukum yang berlaku di kalangan mereka, membela kepentingan dan kesejahteraan bersama terhadap serangan dari luar dan menyelenggarakan cita-cita kemakmuran bersama baik di lapangan kerohanian maupun materi. Hassan Shadily dkk; Ensiklopedi Indonesia 3 (Jakarta: Ichtiar Baru-Van Houve, 1983), 2345.

${ }^{42}$ Damanhuri Zuhri, "Mari Berwakaf Uang", Tabloid Republika, edisi 9 Oktober 2009, 03.
} 
dunia $^{43}$ berpotensi menjadi salah satu kekuatan ekonomi umat di dunia. Sayangnya, potensi yang demikian besar ini belum digarap secara maksimal. Salah satu kekuatan umat Islam di Indonesia itu adalah wakaf. Wakaf uang bisa diibaratkan sebagai raksasa yang tertidur. Bila kekuatan raksasa ini dibangunkan, boleh jadi wakaf uang akan menjadi salah satu andalan umat Islam. Apalagi setiap umat Islam bisa berwakaf uang, tanpa harus menunggu kaya. Menurut Mustofa, potensi wakaf uang itu bisa dicapai jika semua elemen baik pemerintah maupun lembaga-lembaga swasta bergandeng tangan mengkampanyekan gerakan wakaf uang. Semua elemen harus mendukung gerakan ini. Direktur Tabung Wakaf Indonesia (TWI), Zaim Saidi mengungkapkan, potensi wakaf di Indonesia dapat mencapai sepertiga kekayaan umat Muslim. Potensi itu, menurut dia diukur dari anjuran Rasulullah untuk berwakaf sebesar sepertiga harta yang dimiliki. Jadi potensinya memang luar biasa. Menurut Zaim, dalam masyarakat Muslim dikenal tiga jenis wakaf. Jenis wakaf yang pertama adalah wakaf yang dilakukan oleh seseorang untuk kepentingan umum (waqf al-khairi); jenis wakaf yang kedua adalah wakaf yang dilakukan seseorang demi sanak dan kerabatnya (waqf al-ahli); dan jenis wakaf yang ketiga, adalah wakaf seperti yang dilakukan oleh Bani Najjar yang membangun masjid secara bergotong royong untuk kepentingan lebih banyak orang lagi (waqf al-syuyu'i). Waqf al-syuyu'i inilah yang kemudian diartikan sebagai wakaf uang. ${ }^{44}$ Menurut Mustofa,

\footnotetext{
${ }^{43}$ Indonesia berpenduduk muslim terbesar di dunia dapat dilihat dari sepuluh besar negara berpenduduk muslim di seluruh penjuru dunia. Ada negara di mana Muslim menjadi mayoritas pun menjadi komunitas minoritas. Sepuluh negara dan persentasi penduduk Muslimnya: 1). Indonesia penduduk 202.867 .000 jiwa $(88,2 \%$ Muslim); 2). Pakistan penduduk 174.082 .000 jiwa (96,3\% Muslim); 3). India penduduk 160.945 .000 jiwa (13,4\% Muslim); 4). Bangladesh penduduk 145.312 .000 jiwa (89,6\% Muslim); 5). Mesir penduduk 78.513.000 jiwa (94,6\% Muslim); 6). Nigeria penduduik 78.056.000 (50,4\% Muslim); 7). Iran. Penduduk 73.777.000 jiwa (99,4\% Muslim); 8). Turki penduduk 73.619.000 jiwa (sekitar 98\% Muslim); 9). AlJazair penduduk 34.199.00 jiwa (98\% Muslim); dan 10). Maroko penduduk 31 juta 993.000 jiwa (99\% Muslim). Dan di lihat dari dunia saat ini, satu dari empat penduduk dunia Muslim. Menurut laporan yang dirilis Pew Forum on Religion on Public Life dengan judul "Mapping the Global Muslim Population", terdapat 1,57 miliar Muslim di seluruh dunia. Jumlah ini merepresentasikan $23 \%$ dari populasi dunia yang mencapai 6,8 miliar jiwa. Sementara, berdasarkan proyeksi World Religions Database tahun 2005, jumlah penganut Kristen di seluruh dunia mencapai 2,25 miliar orang. Menurut Brian Grim, peneliti senior di Pew Forum, ia merasa terkejut dengan terungkapnya jumlah Muslim di seluruh dunia itu. "Secara keseluruhan jumlahnya lebih tinggi di bandingkan dengan yang diperkirakan". Ia menyatakan, berdasarkan laporan itu 1 dari 4 orang di dunia adalah Muslim; dan 2 dari 3 orang di Asia adalah Muslim, terbentang dari Indonesia hingga Turki. Berdasarkan laporan ini, India yang menjadi Negara berpenduduk mayoritas Hindu, memiliki lebih banyak Muslim di bandingkan negara lainnya, kecuali Indonesia dan Pakistan. Jumlah Muslim di India bahkan 2 kali lipat lebih banyak dibandingkan Mesir. Tidak hanya itu, kejutan lain juga terungkap, China, memiliki jumlah Muslim lebih banyak daripada di Suriah. Sedangkan Jerman, jumlah Muslimnya juga lebih banyak daripada Libanon. Sementara jumlah Muslim di Rusia, lebih banyak daripada gabungan jumlah Muslim di Yordania dan Libya. Menurut Reza Aslan, penulis buku berjudul No God but God laporan ini memiliki implikasi pada kebijakan Amerika Serikat (AS). Ia menyatakan AS tak bisa lagi hanya berfokus di Timur Tengah. Ini artinya, kata Aslan, kebijakan luar negeri AS terkait upaya menjalin hubungan lebih baik dengan dunia Islam harus fokus di Asia Selatan dan Tenggara, bukan lagi di Timur Tengah. "Asia Selatan dan Tenggara harus menjadi perhatian”. Menurut Grim, Pew Forum menghabiskan waktu hampir tiga tahun untuk melakukan analisis data dari 232 negara dan wilayah. Tujuannya jelas, untuk mendapatkan gambaran yang komprehensif mengenai jumlah Muslim di dunia. Alan Cooperman, salah satu direktur penelitian Pew Forum, mengungkapkan, ada sejumlah negara yang diperkirakan tak ada Muslimnya sama sekali, namun ternyata jumlah Muslimnya besar. Negara-negara tersebut adalah India, Rusia, dan China. Menurut Cooperman, sebagian orangjuga berpikir; populasi Muslim Eropa hanya terbentuk dari para imigran. Ternyata fakta ini hanya benar di Eropa Barat. Di bagian Eropa lainnya, seperti Rusia, Albania, dan Kosovo, Muslim adalah penduduk asli negara itu. Republika, "Satu Dari Empat Penduduk Dunia Muslim“, Republika, edisi 9 Oktober 2009, 12.

${ }^{44}$ Heri Ruslan, "Wakaf Uang Potensinya Sungguh Luar Biasa“, Tabloid Republika, edisi 9 Oktober 2009, 4.
} 
setiap umat Islam bisa berwakaf uang, tanpa harus menunggu menjadi orang kaya yang memiliki lahan dan bangunan. ${ }^{45}$

Wakaf uang yang luar biasa besarnya tersebut oleh nadhi $\gg$ diinvestasikan di tanah-tanah wakaf dan dikembangkan sesuai dengan model-model pembangunan wakaf dalam UndangUndang Nomor 41 Tahun 2004 tentang Wakaf, dalam Pasal 43 ayat 2 ada pengumpulan, investasi, penanaman modal, produksi, kemitraan, perdagangan, perindustrian, pengembangan teknologi, pembangunan gedung, hotel, rumah sakit, rumah kos, apartemen, rumah susun, pasar swalayan, pertokoan, perkantoran, sarana pendidikan dan kesehatan dan pula investasi di tanah-tanah wakaf yang strategis dan marketnya bagus dibangun objek-objek pariwisata agama di dalamnya lengkap ada masjid, mushalla, hotel dan tamannya yang artistik yang menampilkan seni budaya Islam yang tinggi-modern menyenangkan, menggembirakan, menambah semangat hidup, menyejukkan hati dan membahagiakan pengunjung betapa besar dan dahsyat kumulasi kapital dan ekonomi yang dapat dihasilkan dan betapa besar dapat membuka lapangan kerja yang pengangguran terdidik di Indonesia tahun 2009 sebanyak 9,289 juta orang dan betapa besar hasil pengelolaan dan pengembangan wakaf di Indonesia untuk kesejahteraan umat, bangsa dan negara Indonesia. Nadhi $\triangleright$ adalah penerima, pengelola dan pengembang harta benda wakaf. Oleh karena itu, nadhi $\gg$ harus memiliki pengetahuan dan wawasan yang luas dan harus melakukan tindakan Plan-Do-Check-Act Cycle (siklus PDCA) proses empat langkah untuk produktif wakaf bermutu.

\section{Peran Badan Wakaf Indonesia dalam Pengembangan Wakaf Uang di Indonesia}

Lahirnya Undang-Undang Nomor 41 Tahun 2004 juga membawa konsekuensi bagi sistem pengelolaan wakaf di Indonesia agar lebih profesional dan independen. Untuk itu diperlukan suatu lembaga baru yang memiliki kapasitas dan kapabilitas dalam memberdayakan aset wakaf di Indonesia agar lebih produktif. Pentingnya pembentukan sebuah lembaga wakaf nasional yang bersifat independen diperlukan dalam rangka untuk membina nadhi $\gg$ (pengurus harta wakaf) dalam mengelola dan mengembangkan harta benda wakaf baik secara nasional maupun internasional.

Badan Wakaf Indonesia pun lahir sebagai jawaban bagi pengembangan pengelolaan perwakafan Indonesia dengan lebih profesional dan modern sehingga menghasilkan manfaat wakaf yang dapat mensejahterakan umat. Badan Wakaf Indonesia menduduki peran kunci, selain berfungsi sebagai nadhi», BWI juga akan sebagai pembina nadhi $\gg$ sehingga harta benda wakaf dapat dikelola dan dikembangkan secara produktif.

Potensi wakaf uang pada tahun 2007 untuk Indonesia nilainya sekitar tiga triliun per tahun. Jumlah ini memang masih jauh bila dibandingkan dengan potensi zakat yang nilainya sekitar 21 triliun menurut data PIRAC. ${ }^{46}$ Tetapi perbedaan yang sangat signifikan adalah bahwa dana wakaf pokoknya akan tetap utuh dan semakin terakumulasi dari tahun ke tahun. Hal ini berbeda dengan dana zakat yang akan langsung habis dalam satu tahun. Tetapi angka tiga triliun tersebut masih merupakan data yang terlalu muluk karena faktanya di lapangan, penghimpunan dana wakaf uang di Indonesia masih sangat sedikit. Sebagai contoh Tabung

\footnotetext{
${ }^{45}$ Ibid.

${ }^{46}$ Lihat Peran BWI dalam Pengembangan Wakaf Indonesia http://sigitsoebroto.blogspot.com/2009/06/peranbwi. Diakses pada 23 Juni 2016.
} 
Wakaf Indonesia (TWI) yang dikonsentrasikan untuk penghimpunan dan pengelolaan wakaf uang baru mampu mengumpulkan dana wakaf uang sekitar dua miliar per tahun. Oleh karena itu Badan Wakaf Indonesia seharusnya tidak hanya berfungsi sebagai lembaga yang mengelola wakaf secara independen dan mandiri agar dana yang dikelola lebih produktif, akan tetapi fungsi penyadaran dan sosialisasi terhadap masalah wakaf, baik fungsi dan manfaatnya kepada masyarakat harus juga dimainkan perannya oleh Badan Wakaf Indonesia itu sendiri. Selama ini memang efektivitas untuk memberdayakan wakaf dan juga menarik dana wakaf dari masyarakat untuk dikelola oleh lembaga wakaf belum maksimal. Hal ini karena realisasi pencapaian di lapangan dengan potensi wakaf di masyarakat sendiri belum berbanding lurus dan mencapai titik yang ideal.

Jika menengok keberhasilan dari Negara Bangladesh dalam upaya pengelolaan wakaf tunai dengan dilakukannya sosialisasi tentang pengenalan Sertifikat Wakaf Tunai, ternyata dapat mengubah kebiasaan dan pemahaman lama di tengah-tengah masyarakat Bangladesh, di mana biasanya kebanyakan orang yang berwakaf diidentikkan hanya melibatkan orang-orang kaya saja. Dengan adanya Sertifikat Wakaf Tunai yang dikeluarkan oleh Social Investment Bank Limited (SIBL) memang dibuat dengan nilai yang dapat dijangkau oleh mayoritas masyarakat Islam. Pola seperti ini, menjadikan ibadah wakaf bukan hanya didominasi orangorang kaya, tetapi juga dapat diamalkan oleh orang banyak sesuai dengan keadaan keuangan masing-masing. Selain itu, pola Sertifikat Wakaf Tunai seperti ini lebih mudah untuk diamalkan, karena tidak memerlukan proses administrasi yang rumit seperti halnya wakaf atas benda tidak bergerak. ${ }^{47}$

Badan Wakaf Indonesia mempunyai fungsi sangat strategis dalam membantu, baik dalam pembiayaan, pembinaan maupun pengawasan terhadap para nadhi $\gg$ untuk dapat melakukan pengelolaan wakaf secara lebih produktif. Pola organisasi dan kelembagaan Badan Wakaf Indonesia harus mampu merespon persoalan-persoalan yang dihadapi oleh masyarakat pada umumnya dan umat Islam pada khususnya. Di tingkat masyarakat, persoalan yang paling mendasar adalah kemiskinan, baik dalam arti khsusus, yaitu seperti yang dicerminkan dengan tingkat pendapatan masyarakat, maupun dalam arti luas yang mencakup aspek kesehatan, pendidikan atau pemenuhan hak-hak asasi pada umumnya.

Untuk alternatif sumber dana, wakaf yang dikelola oleh sebuah lembaga nasional seperti Badan Wakaf Indonesia misalnya, seharusnya dapat dijadikan sumber dana potensial dalam mengatasi permasalahan sosial seperti kemiskinan dan aspek permasalahan turunnya. Masalah sosial kemasyarakatan tidak hanya menjadi tanggung jawab negara semata saja sebagai sebuah institusi tertinggi dari penyelenggaraan tata pemerintahan, namun menjadi persoalan bersama yang harus diselesaikan dengan bersama-sama pula. Organisasi kemasyarakatan

\footnotetext{
${ }^{47}$ Badan Wakaf Indonesia (BWI) sebagai lembaga wakaf nasional kiranya dapat mencontoh pola pengembangan wakaf yang ada di Bangladesh atau setidaknya mengadobsi dengan menyesuaikan karakteristik budaya masyarakat Indonesia. Diversifikasi program dan juga instrumen kebijakan yang lebih mudah dicerna dan mengakomadasi budaya-budaya lokal yang ada di Indonesia, dapat diterapkan mulai saat ini seperti yang terjadi di Bangladesh. Keragaman budaya lokal yang sangat dinamis dan suku bangsa yang banyak di negara kita, menjadi permasalahan sekaligus potensi tersendiri bagi Badan Wakaf Indonesia dalam menghimpun dan mengelola dana masyarakat secara luas. Jika pendekatan yang dilakukan kepada masyarakat di lakukan sesuai dengan budaya local yang ada dimasyarakat, bukan tidak mungkin efektivitas penghimpunan dana dan pengelolaan dana akan tercipta dan lebih efektif. Lihat Peran BWI dalam Pengembangan Wakaf Indonesia http://sigitsoebroto.blogspot.com/2009/06/peran-bwi.
} 
yang berbasis Islam turut juga bertanggung jawab dengan membangun gerakan sosial yang lebih realistis dalam mengatasi permasalahan ini. Akses sumber daya wakaf patut juga diberikan dan dibuka secara luas kepada organisasi-organisasi Islam dan non Islam yang berafiliasi sosial agar masalah kemiskinan yang ada dapat teratasi. Peran Badan Wakaf Indonesia menjadi semakin penting dalam memainkan perannya. Tugas pokok seperti mengadministrasi sampai dengan pengelolaan dana wakaf harus selaras dengan program yang telah dibuat. Acuan waktu yang dipakai juga harus dapat di ukur seperti jangka pendek, menengah dan panjang karena hal ini akan terkait dengan visi dan misi organisasi yang dibuat.

Dalam membiayai pembangunan dan pengentasan kemiskinan, Badan Wakaf Indonesia bersama pemerintah juga dapat bersinergi dalam rangka memanfaatkan sumber daya wakaf untuk kepentingan bangsa. Potensi dana wakaf yang sangat besar dapat dikelola untuk sumber pendanaan pemberdayaan ekonomi umat secara umum. Wakaf sebenarnya juga dapat menjadi alternatif solusi bagi pendanaan pembangunan negara jika dikelola dengan baik. Selama ini secara konvensional dana pinjaman untuk pembiayaan utang negara diambil dari utang luar negeri atau dalam negeri. Instrumen yang dipakai pemerintah pun tidak jauh-jauh dari Surat Utang Negara, penerbitan ORI dan instrumen pinjaman modal lain yang intinya berusaha menarik dana masyarakat untuk dipinjam oleh negara dalam rangka membiayai pembangunan. Wakaf sebenarnya dapat memainkan peran sebagai instrument pengganti jika dikelola dengan maksimal. Sayangnya pengelolaan sumber dana wakaf ini masih kurang maksimal. Sehingga untuk menuju ke arah itu masih dibutuhkan waktu yang lama.

Lembaga wakaf nasional seperti Badan Wakaf Indonesia, seharusnya sudah mulai dapat menjalin kerja sama dengan pihak swasta dalam pengelolaan wakaf untuk produktifitas benda wakaf yang dikelolanya. Aset wakaf yang ada dapat dibedakan secara kolektif dengan swasta profesional untuk mengerjakan proyek-proyek yang mengikutsertakan aset wakaf tersebut sebagai bagian utama kegiatan usaha, seperti di bidang pertanian.

Mencermati lebih lanjut mengenai faktor penyebab utama mengapa potensi wakaf di Indonesia belum produktif, pada prinsipnya masalah ini terletak di tangan nadhi», selaku pemegang amanah dari wałif (orang yang berwakaf) untuk mengelola dan mengembangkan harta wakaf. Artinya, pengelolaan harta wakaf belum dilakukan secara profesional.

Dilihat dari cara pengelolaannya selama ini, ada tiga tipe nadhi $\gg$ di Indonesia. Pertama, dikelola secara tradisional. Harta wakaf masih dikelola dan ditempatkan sebagai ajaran murni yang dimasukkan dalam kategori ibadah semata. Seperti untuk kepentingan pembangunan masjid, madrasah, mushala dan kuburan. Kedua, harta wakaf dikelola semi profesional. Cara pengelolaannya masih tradisional, namun para pengurus (nadhi $\rtimes$ ) sudah mulai memahami untuk melakukan pengembangan harta wakaf lebih produktif. Namun, tingkat kemampuan dan manajerial nadhi $\gg$ masih terbatas. Ketiga, harta wakaf dikelola secara profesional. Nadhi dituntut mampu memaksimalkan harta wakaf untuk kepentingan yang lebih produktif dan dikelola secara profesional dan mandiri.

Peran Badan Wakaf Indonesia selaku lembaga independen yang lahir berdasarkan amanat Undang-Undang Nomor 41 Tahun 2004 tentang Wakaf, memiliki tanggung jawab besar dalam memajukan dan mengembangkan perwakafan di Indonesia (Pasal 47). Selain itu, Badan Wakaf Indonesia juga bertanggung jawab dalam membina nadhi $\gg$ agar menjadi lebih 
profesional. Misalnya dengan menyelenggarakan sejumlah pelatihan pengelolaan harta wakaf, menerbitkan buku-buku wakaf dan lainnya. Apalagi, pengembangan wakaf kini didukung oleh Undang-Undang Nomor 41 Tahun 2004 tentang Wakaf dan Peraturan Pemerintah Nomor 42 Tahun 2006 tentang Pelaksanaan Undang-Undang Nomor 41 tersebut, maka tidak ada alasan lagi jika pengelolaan dan pengembangan harta wakaf di Indonesia tertinggal dengan negara-negara lain di dunia, karena Indonesia sebagai negara dengan jumlah penduduk muslim terbesar.

Di era otonomi daerah yang semakin menguat, potensi pengembangan wakaf juga semakin besar jika disinergikan dengan peraturan dan keinginan daerah. Tentunya hal ini akan menjadi hal yang menarik karena otonomi daerah sangat memberikan peluang bagi pengembangan dan pemberdayaan pengelolaan wakaf itu sendiri. Pola pengembangan organisasi Badan Wakaf Indonesia sendiri sudah harus mulai berorientasi kepada daerah dengan menyiapkan SDM nadhi di daerah agar lebih profesional. Fungsi-fungsi yang melekat di tubuh Badan Wakaf Indonesia seperti fungsi motivator, fungsi fasilitator, fungsi regulator, fungsi education, dan fungsi pendukung lainnya harus selaras dan tidak over lapping dalam implementasinya. Diperlukan sistem organisasi yang tanggap dengan tantangan zaman dan perubahan yang dinamis di masyarakat dalam mengefektifkan wakaf sebagai alternatif sumber daya untuk penciptaan kesejahteraan sosial masyarakat.

Kalau diperhatikan lebih dalam, selama ini masih banyak sumber daya daerah yang belum dikelola dengan baik. Jika masing-masing daerah yang memiliki sumber daya yang cukup memadai, bukan tidak mungkin bahwa lembaga perwakafan dibentuk melalui peraturan daerah dan khusus mengatur tentang kemungkinan dan kelayakan wakaf, baik yang menyangkut wakaf konvensional, wakaf uang, dan bentuk wakaf lain. Sehingga persoalan wakaf tidak lagi menjadi otoritas pemerintah pusat atau lembaga tertentu yang ditunjuk pemerintah pusat, melainkan juga mejadi program produktif masing-masing daerah yang akan membawa kemaslahatan bersama bagi masyarakat daerah juga.

Untuk menjalankan semua rencana praktis di atas, maka peran Badan Wakaf Indonesia sebagai lembaga pengelola harta (dana tunai) wakaf nasional memerlukan sumber daya manusia yang baik sesuai dengan merit system organisasi dan kecakapan ilmu yang dimiliki dengan tugas dan tanggung jawab yang diembannya.

Peningkatan kualitas SDM pengelola wakaf seperti nadhi diperlukan karena sudah menjadi sebuah rahasia umum bahwa lembaga keummatan selalu identik dengan ketidakprofesionalan, sehingga lembaga keummatan termasuk lembaga wakaf bukan menjadi pilihan awal tenaga kerja nomor satu. Lembaga ini selalu menjadi pilihan nomor dua atau bahkan pilihan akhir ketika tidak ada perusahaan atau lembaga lain yang menampungnya. Dan lebih parahnya adalah menjadi tempat pembuangan SDM yang sudah tidak produktif. Sehingga tidak salah apabila kinerja lembaga keummatan termasuk wakaf tidak dapat tumbuh secara cepat, baik tumbuh dalam penghimpunannya maupun pengelolaannya. Dan menjadi tugas bersama untuk meningkatkan kualitas SDM lembaga wakaf ini, sehingga nantinya tidak terdengar ada aset wakaf yang tidak dikelola, atau terdapat aset wakaf yang hilang, diperebutkan dan lain sebagainya. 


\section{Kesimpulan}

Dari uraian tersebut di atas dapat disimpulkan, bahwa peran Badan Wakaf Indonesia dalam mengembangkan prospek wakaf uang di Indonesia paling tidak dapat dipetakan pada hal-hal berikut ini. Pertama, pembinaan tergadap nadhi $\triangleright$ yang profesional, khususnya terhadap individu atau badan hukum yang diberi wewenang dan tanggung jawab sebagai nadhi $\gg$ wakaf uang. Peningkatan kualitas sumber daya manusia nadhi $\gg$ ini dapat berbentuk kebijakan yang sifatnya tentatif atau bahkan yang ajeg, agar rasa dan kemanfaatannya terlihat bagi nadhi . Kedua, melibatkan mitra-mitra bisnis strategis yang bergerak di bidang jasa keuangan (khususnya berbasis syariah), seperti bank, koperasi, BMT dan sejenisnya dalam proses promosi dan sosialisasi wakaf uang yang sedang dikembangkan oleh Badan Wakaf Indonesia, ini semua agar prospeknya dan kepercayaan masyarakat terhadap wakaf uang di Badan Wakaf Indonesia tumbuh subur.

\section{Daftar Rujukan}

al-Amadi, Abu Su'ud Muhammad ibn Muhammad ibn Mushthafa. Risatah fi \awazWaqfan-

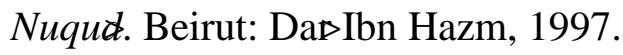

al-Anshari, Abi Yahya Zakariya. Fath \}al-Wahha๖, Juz I. Semarang: Toha Putra, t.th.

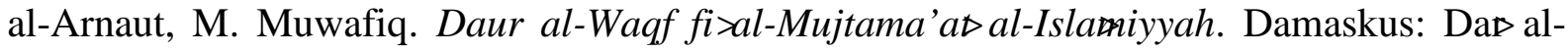
Fikr, 2000.

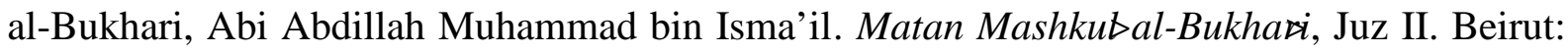
Daßal-Fikr, 1994.

al-Munawwar, Said Agil Husain. Hukum Islam dan Pluralitas Sosial. Jakarta: Penamadani, 2004.

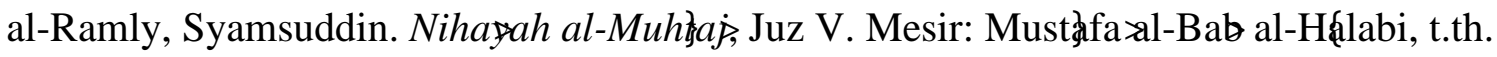

al-Shan'ani, Muhammad bin Isma'il al-Kahlani. Subul al-Salaær, Juz III. Semarang: Toha Putra, t.t.

Depatemen Agama Republik Indonesia, Proses Lahirnya Undang-Undang Nomor 41 Tahun 2004 Tentang Wakaf. Jakarta: Direktorat Pemberdayaan Wakaf Direktorat Jenderal Bimbingan Masyarakat Islam, 2006.

Undang-Undang Nomor 41 Tahun 2004 tentang Wakaf dan Peraturan Pemerintah Nomor 42 Tahun 2006 tentang Pelaksanaan Undang-Undang Nomor 41 Tahun 2004 tentang Wakaf, Jakarta: Departemen Agama RI. Ditjen Bimas Islam, 2007. Djunaidi, Ahmad. Menuju Era Wakaf Produktif. Jakarta: Map Mumtaz Publizhing, 2008. Ghanim, Ibrahim al-Bayumi. al-Auqaßwa al-Siyasah fi Misła, Mesir: Da®al-Ashshirk, t.th. Halim, Abdul. Hukum Perwakafan di Indonesia. Jakarta: Ciputat Press, 2005.

Harahap, Sumuran. "Kontroversi Pembentukan Unit Kerja Presiden Untuk Program Pengelolaan Reformasi Indonesia (Suatu Tinjauan Analisis Kritis Dari Aspek Kebijakan Publik)", Tesis--Sekolah Tinggi Administrasi Publik YAPPAN, Jakarta, 2007.

Mannan, M.A., "Beyond the Malaysian Twin Towers: Mobilization Efforts of Cash-Waqf Fund at Local, National and International Levels for Development of Social Infrastructure of the Islamic Ummah and Establishment of World Social Bank", International Seminar on Awqaf 2008 - Awqaf: The Social and Economic Empowerment of the Ummah, Johor Bahru, 11-12 Agustus 2008, Persada Johor International 
54 Peran Badan Wakaf Indonesia (B W I)

Convention Center.

Mughniyah, Muhammad Jawwad. Fiqh Lima Mazhab. Jakarta: Basrie Press, 1997.

Rofiq, Ahmad. Fiqih Kontekstual dari Normatif ke Pemaknaan Sosial. Yogyakarta: Pustaka Pelajar, 2004.

. Pembaharuan Hukum Islam di Indonesia. Yogyakarta: Gama Media, 2001.

Ruslan, Heri. "Wakaf Uang Potensinya Sungguh Luar Biasa", Tabloid Republika, edisi 9 Oktober 2009.

Sabiq, Sayyid. Fiqh Sunnah. Bandung: al-Ma'arif, 1987.

Shadily, Hassan dkk. Ensiklopedi Indonesia 3. Jakarta: Ichtiar Baru-Van Houve, 1983.

Usman, Suparman. Hukum Perwakafan di Indonesia. Serang: Darul Ulum Press, 1999.

Zuhri, Damanhuri. "Mari Berwakaf Uang”, Tabloid Republika, edisi 9 Oktober 2009. 